\title{
A Critical Research of Green Building Assessment Systems in Malaysia Context
}

\author{
Ong Boon Zian, Soo-Fen Fam, ChuanZun Liang, Sentot Imam Wahjono, Tan Ying Ying
}

\begin{abstract}
Excessive development has led to main changes in world civilization, including the societal, natural environment, and economical. Construction industry is significant contributor towards numerous environmental effects. Therefore, the concept of implementation "green" has been concern. Green building has become a flagship for sustainable development that responsible for balancing long-term environmental, social health and social economic. Green building assessment systems have been introduced to evaluate the sustainability level of the green buildings such as GBI, PH JKR, GreenRE and MyCREST. Although green building assessment have been the study of many researchers over the past twenty years, it is still no systematic assessment of the detailed criteria for each assessment systems. Therefore, this research aimed to conduct critical review of green building assessment systems in Malaysia. This research is conducted through comparison analysis where the points allocated for each criteria is being measured and compared. It founds that energy efficiency criteria is the most widely used in green building assessment systems followed by water efficiency and innovations. This research showed that each green building assessment systems showed different culture and they used different criteria in evaluating the sustainability level of the green building projects. The outcomes of this research is expected to create awareness among construction industry players or decision makers to understand better and have a different perspective toward current green building assessment systems.
\end{abstract}

Index Terms: Green building criteria, green building assessment systems, sustainable development.

\section{INTRODUCTION}

Excessive development leads to major changes in the world civilization, including the societal, economical, and natural environment [1] while construction industry is an important contributor to the world economy, as the construction industry accounts for a huge proportion of the gross domestic product of most countries [2]. The industrial sector, through its role in society, is significant contributor towards the pollution and exploitation of environment [3]. Although construction industry has contributed a lot to the GDP of country, industry cannot be separated from its negative impact on degrading of natural environment [2]. The industry used a lot of natural resources and its adverse environmental impacts are widely concerned [4]. The industrial sector, through its role in society, has contributed significantly to pollution and exploitation of the environment [3]. Buildings has become the main energy consumers in today's cities that account for $70 \%$ of total

Revised Manuscript Received on September 14, 2019.

Ong Boon Zian, Universiti Teknikal Malaysia Melaka, Malaysia.

Soo-Fen Fam, Universiti Teknikal Malaysia Melaka, Malaysia.

Chuan Zun Liang, Universiti Malaysia Pahang, Malaysia.

Sentot Imam Wahjono, Universitas Muhammadiyah Surabaya, Indonesia.

Tan YingYing, Universiti Teknikal Malaysia Melaka, Malaysia. (Email - famsoofen@utem.edu.my).

electricity consumption and $30 \%$ to $40 \%$ of total energy consumption [5]. Besides that, commercial, industrial, and residential buildings produce more than $38 \%$ of carbon dioxide emissions compared to $10 \%$ of world's carbon dioxide emissions [1]. Buildings have contributed to the pollution of environment and negative impact to the flora, fauna as well as human beings. These buildings are responsible for a large amount of energy use, resource consumption and greenhouse gas emissions worldwide. The excessive emission has led to global warming and other environment problem [6]. It is important to gauge the town sustainability [7]. Increasing emphasis on sustainability is driving the governance of the construction and built environment to move rapidly [8]. To guarantee the sustainability of social life, green practices has become the responsibility of the construction industrial players [9]. Therefore, the concept of implementation "green" has been concern.

In today cities, building has consumed a lot of electricity and they have bring a lot of negative impacts to the environment and the society. Increasing emphasis on sustainability is driving the governance of the construction and built environment to move rapidly [8]. Therefore, green building has become an unavoidable trend in the industry, which has greatly affected the environment for social development, the economy and a series of industries. [10]. As stated by United States Environmental Protection Agency [11], a green building can be defined as the process from selection of site to design, building, operating, maintaining, refurbishing and deconstructing, generating structures, and implement environmentally responsible and resource efficient processes throughout the lifecycle of the buildings. Besides that, green building can also be described as building with design, construction or operation, eliminates or minimize side impact and generate a good impact on natural environment and climate [12]. Green buildings encourage a healthier, greener environment and provide the same economic, comfort, stability and design and architectural values as classic buildings [13].

Green buildings are mixing a large number of exercises, methods and skills to minimize and eliminate the side impact of buildings towards environment and people health [14]. In context of technology, the company should well fit to implementing green practice [15]. Green buildings are also an environmentally responsible and resource efficient structure throughout their life cycle [5]. Although the idea of 'going green' has been concerned in construction industry for past years, official statistics indicate that the industry continues to be a main energy consumer [16]. 
One of the reason could because of the relatively passive attitude of theplayers towards adopting sustainable solutions [17].

In Malaysia, Many companies have launched green building assessment systems to reduce/minimize natural resource consumption and control pollution [18]. Relevant and accurate indicators can provide policymakers with a clearer picture of what is currently happening in the country [19]. Fig. 1 showed the green building assessment systems in Malaysia. All of the green building assessment systems has their own assessment criteria to evaluate the project. The green building assessment systems is developed to ensure all the welfare of buildings' occupants and entire environment [20]. It can be used as a guideline to asses buildings' sustainability performance and translates the assessment into an overall standardized ranking that can be compared to other buildings [21].

Although green building assessment certification has been study of many researchers over the past twenty years, there is no systematic assessment of the detailed criteria for each assessment system yet. Some papers are focus on the trends and credits of the personal assessment system, but there have no established a comprehensive comparison of green building assessment systems [18]. For example, in [14] conducted comment on Green Building Index(GBI) in Malaysia while review on other green building assessment systems are not conducted. Besides that, in [22] focused only on GBI and the research did not focus on other assessment systems such as MyCREST because the researchers stated that MyCREST is still fresh in Malaysia. There is a lack of research conducted to make comparison between green building assessment systems in Malaysia. Therefore, this research paper aims to conduct critical review of green building assessment systems in Malaysia that focus on GBI, GreenRE, MyCREST and PH JKR. This paper will discover each of the assessment system and make a comparison between each of the assessment system in Malaysia. Furthermore, this paper will also assess the criteria stated in different green building assessment systems.

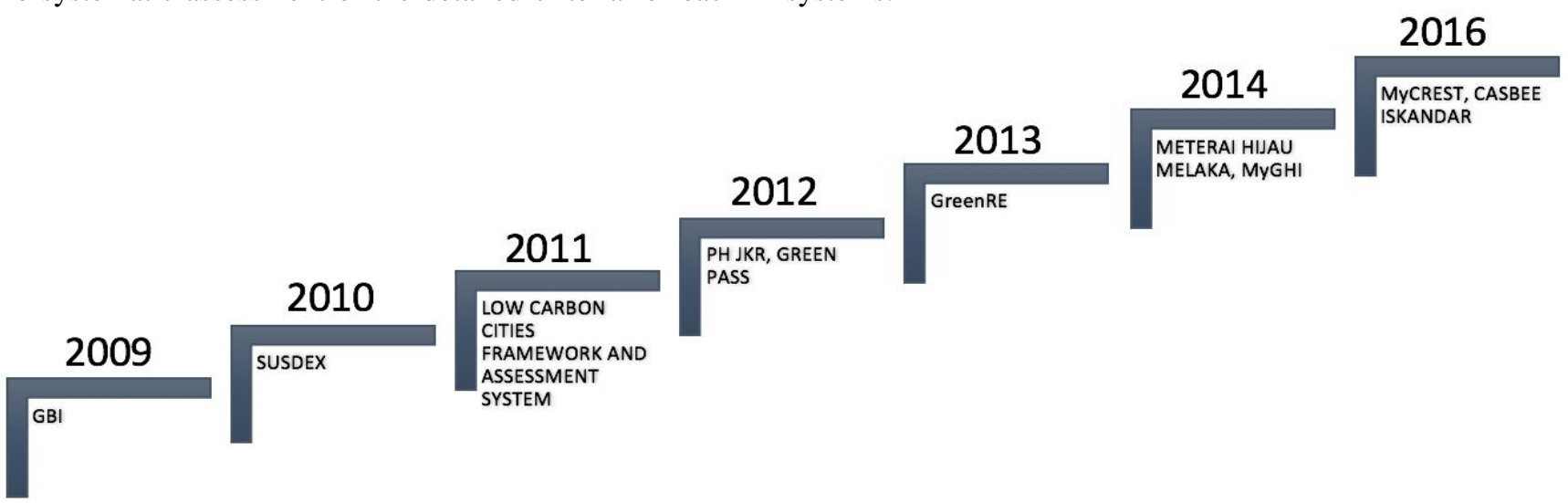

Fig. 1: Introduction of Green Building Assessment Systems in Malaysia

\section{METHODOLOGY}

This research seeks to study and investigate green building assessment systems in Malaysia namely GBI, GreenRE, PH JKR, and MyCREST. The research data in this research was carried out through systematic desktop search via online scientific database such as Scopus and Google Scholar. Researcher has to identify the relevant journal, article or review papers available in the database. Since there are too many papers related to green building, some search keywords such as "GBI", "PH JKR", "GreenRE", "MyCREST" and "sustainable development" were used to narrow down the focus. Content analysis on existing literatures are adopted to deeply understand the contents in each of the green building assessment systems. After searching information through papers, the latest version of manual for GBI, PHJKR, GreenRE and MyCREST were examined to determine the contents and focus, along with similarities and differences to understand their support to sustainability.

\section{RESULTS AND DISCUSSION}

A. Overview of Green Building Assessment Systems(GBI, PH JKR, GreenRE and MyCREST)

GBI, PH JKR, GreenRE and MyCREST were established by different parties and each of the green building assessment systems consists of different criteria weightage in evaluating the sustainability level of a project. The timeline for development of the green building assessment systems displayed in Fig. 2 and Table 1. It can be noticed that GBI has been established since 2009 and it was the earliest green building assessment system compare to others. GBI rating system was established jointly by Association of Consulting Engineers Malaysia (ACEM) and PertubuhanArkitek Malaysia (PAM) [14]. After GBI has been introduced, others green building assessment systems has been established into the market. In these green building rating tools, the criteria perform several functions in assessing the responsiveness of the building toward the sustainable development and it also support the decisionmaking process [23]. Each of the green building assessment systems have different culture and criteria in accessing the green building projects. GreenRE has made frequent updates in order to best meet the market needs. Besides that, others green building assessment systems also showed continue updates on their manual. This proves that all assessment systems are working to modify and update their standards more frequently so that they can be tracked as fast as sustainable buildings develop [18].

Published By: Blue Eyes Intelligence Engineering \& Sciences Publication 


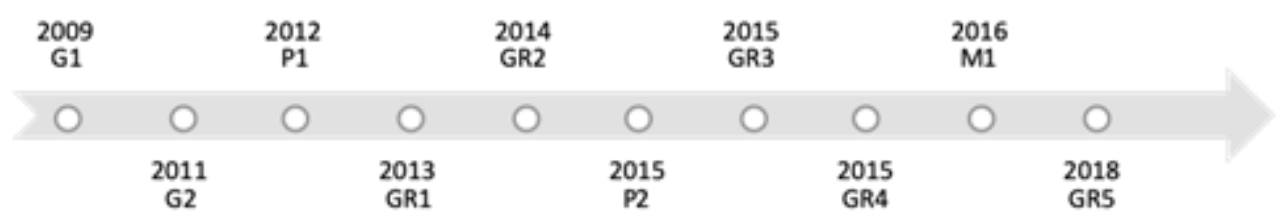

Fig. 2: Timeline for development of GBI, GreenRE, PH JKR and MyCREST

Table 1: Timeline for development of GBI, GreenRE, PH JKR and MyCREST

\begin{tabular}{|c|c|c|c|c|}
\hline \multirow{2}{*}{\multicolumn{3}{|c|}{$\begin{array}{l}2009 \text { G1 } \\
2009 \text { GBI Version } 1.00(\text { NRNC) }\end{array}$}} & \multicolumn{2}{|c|}{$2011 \mathrm{G} 2$} \\
\hline & & & \multicolumn{2}{|c|}{2011 GBI Version 1.05 (NRNC) } \\
\hline 2013 GR1 & 2014 GR2 & 2015 GR3 & 2015 GR4 & 2018 GR5 \\
\hline $\begin{array}{l}2013 \quad \text { GreenRE } \\
\text { Version 1.1 (NRB) }\end{array}$ & $\begin{array}{l}2014 \quad \text { GreenRE } \\
\text { Version } 1.2(\mathrm{NRB})\end{array}$ & $\begin{array}{ll}2015 & \text { GreenRE } \\
\text { Version } 2.0(\mathrm{NRB})\end{array}$ & $\begin{array}{ll}2015 & \text { GreenRE } \\
\text { Version } 3.0(\mathrm{NRB})\end{array}$ & $\begin{array}{ll}2018 & \text { GreenRE } \\
\text { Version } 3.1(\mathrm{NRB})\end{array}$ \\
\hline \multicolumn{3}{|l|}{$2012 \mathrm{P} 1$} & \multicolumn{2}{|c|}{$2015 \mathrm{P} 2$} \\
\hline \multicolumn{3}{|c|}{2012 PH JKR Version 1.0} & \multicolumn{2}{|c|}{2015 PH JKR Vesion 2.0} \\
\hline \multicolumn{5}{|l|}{$2016 \mathrm{M} 1$} \\
\hline \multicolumn{5}{|c|}{2016 MyCREST Version1.0 } \\
\hline
\end{tabular}

Next, the overview of the GBI, PH JKR, GreenRE and MyCREST are displayed in Table 2. Each of the green building assessment systems is developed by different party. Considering the number of criteria that will be involved in evaluating the green building project, it showed that MyCREST has the highest number of criteria involved [9]. This is because the evaluation criteria will be involved in two stages: design stage and construction stages of building. Next, the number of criteria used in GBI, PH JKR and GreenRE is the same. 6 criteria will be evaluated to identify the sustainability level of the building. It can clearly see that GBI and PH JKR showed the same patterns of criteria when evaluating the green building projects. However, the criteria stated in GreenRE is different. GreenRE does not evaluate sustainable site planning and management while carbon emission of development has been included into the evaluation criteria. GreenRE enable the construction industry players to recognize the carbon emission based on operational carbon footprint computation of the building comprising energy and water consumption. During the construction activity, it is important for the industry to understand the amount of carbon emitted during the project. These assessment systems share the common criteria such as energy efficiency, water efficiency and innovation but the weightage of the criteria in the green building assessment systems is different. Furthermore, the assessment level for green building assessment systems is different as showed in the table below.

\begin{tabular}{|c|c|c|c|c|}
\hline $\begin{array}{l}\text { Green Building } \\
\text { Assessment } \\
\text { System }\end{array}$ & GBI & PH JKR & GreenRE & MyCREST \\
\hline $\begin{array}{l}\text { Organization/ } \\
\text { Department }\end{array}$ & PAM and ACEM & JKR & REHDA & CIDB and JKR \\
\hline Year introduced & 2009 & 2012 & 2013 & 2016 \\
\hline Criteria evaluated & $\begin{array}{l}\text {-Energy } \\
\text { efficiency } \\
\text {-Indoor } \\
\text { environmental } \\
\text { quality } \\
\text {-Sustainable site } \\
\text { planning and } \\
\text { management } \\
\text {-Material and } \\
\text { resources } \\
\text {-Water efficiency } \\
\text {-Innovation }\end{array}$ & $\begin{array}{l}\text {-Sustainable site } \\
\text { planning and } \\
\text { management } \\
\text {-Energy } \\
\text { efficiency } \\
\text {-Indoor } \\
\text { environmental } \\
\text { quality } \\
\text {-Material and } \\
\text { resources } \\
\text {-Water efficiency } \\
\text {-Innovation }\end{array}$ & $\begin{array}{l}\text {-Energy efficiency } \\
\text {-Water efficiency } \\
\text {-Environmental } \\
\text { protection } \\
\text {-Indoor } \\
\text { environmental } \\
\text { quality } \\
\text {-Innovations } \\
\text {-Carbon emission } \\
\text { of development }\end{array}$ & $\begin{array}{l}\text {-Pre-design } \\
\text {-Infrastructure and sequestration } \\
\text {-Energy performance impact } \\
\text {-Occupant and health } \\
\text {-Lowering the embodied carbon } \\
\text {-Water efficiency factors } \\
\text {-Social and cultural sustainability } \\
\text {-Demolition and disposal factors } \\
\text {-Sustainable and carbon initiatives }\end{array}$ \\
\hline $\begin{array}{l}\text { Assessment } \\
\text { approach }\end{array}$ & $\begin{array}{l}\text {-Credit point } \\
\text { based }\end{array}$ & $\begin{array}{l}\text {-Credit point } \\
\text { based }\end{array}$ & -Credit point based & $\begin{array}{l}\text {-Credit point based } \\
\text {-Carbon emission calculation }\end{array}$ \\
\hline Assessment level & $\begin{array}{l}86-100=\text { Platinum } \\
76-85=\text { Gold } \\
66-75=\text { Silver } \\
50-65=\text { Certified }\end{array}$ & $\begin{array}{l}40-49=2 \text { stars } \\
50-69=3 \text { stars } \\
70-84=4 \text { stars } \\
85-100=5 \text { stars }\end{array}$ & $\begin{array}{l}>90=\text { Platinum } \\
85-<90=\text { Gold } \\
75-<85=\text { Silver } \\
50-<75=\text { Bronze }\end{array}$ & $\begin{array}{l}40-49=1 \text { star } \\
50-59=2 \text { stars } \\
60-69=3 \text { stars } \\
70-79=4 \text { stars } \\
80-100=5 \text { stars }\end{array}$ \\
\hline
\end{tabular}


The assessment approach for green building assessment systems are different. GBI used credit point based to evaluate the green building project where credits have been allocated for different criteria. The applicant has to total up the credits obtained for different criteria to determine whether obtain GBI certification. PH also used credit point based to evaluate green building project. However, the assessment approach may differ from GBI. The total points allocated for the credits stated in PH JKR is 130 point and to obtain PH JKR certification, the calculation of assessment is (total points obtained/130 x 100\%). GreenRE also used credit points based but the assessment approach is different. GreenRE approach has divided into energy related requirements and other green requirements. This two requirement has allocated 50 credits each. In order to achieve GreenRE certification, applicants must meet minimum 30 credits for energy related requirements and 20 credits for other green requirements. Lastly, MyCREST used credit point based and carbon emission calculation to evaluate the green building projects. In MyCREST, criterion is a category that contains of a list of sub-criteria carry points and sub-criteria is labelled depending on the extent and verification of its carbon related impact.The project must have achieved at least $50 \%$ of carbon based point in each criterion. The score obtained is based on the total percentage weight given to each criteria under each stage.

B. Green Building Criteria by GBI, PH JKR, GreenRE and MyCREST

Table 3 showed the percentage allocated for different criteria stated in various green building assessment systems and the comparison of criteria respectively. Fig. 3 has demonstrated the comparison of criteria in GBI, GreenRE, PH JKR and MyCREST. It is clearly stated that energy efficiency, innovation and water efficiency is utilized by all of the green building assessment systems followed by indoor environmental quality, material and resources, sustainable site planning and management, carbon emission of development, environmental protection, pre-design, occupant and health, infrastructure and sequestration, social and cultural sustainability, demolition and disposal factors.

Table 3: Comparison of Criteria in GBI, PH JKR, GreenRE and MyCREST

\begin{tabular}{|c|c|c|c|c|c|}
\hline Criteria & GBI (\%) & PH JKR (\%) & GreenRE (\%) & MyCREST (\%) & Total (\%) \\
\hline Energy efficiency & 35 & 37 & 59 & 31 & 40.5 \\
\hline Indoor environmental quality & 21 & 22 & 5 & & 12.0 \\
\hline $\begin{array}{c}\text { Sustainable site planning and } \\
\text { management }\end{array}$ & 16 & 18 & & & 8.5 \\
\hline Material and resources & 11 & 8 & & & 4.75 \\
\hline Water efficiency & 10 & 10 & 7 & 7 & 8.5 \\
\hline Innovation & 7 & 5 & 4 & 6 & 5.5 \\
\hline Environmental protection & & & 23 & & 5.75 \\
\hline $\begin{array}{c}\text { Carbon emission of } \\
\text { development }\end{array}$ & & & 2 & 21 & 5.75 \\
\hline Pre-design & & & & 3 & 0.75 \\
\hline Infrastructure and sequestration & & & & 21 & 5.25 \\
\hline Occupant and health & & & & 4 & 1 \\
\hline $\begin{array}{c}\text { Social and cultural } \\
\text { sustainability }\end{array}$ & & & & 4 & 1 \\
\hline Demolition and disposal factors & & & & 3 & 0.75 \\
\hline Total & 100 & 100 & 100 & 100 & 100 \\
\hline
\end{tabular}

Energy efficiency (EE) plays a critical role in the criteria of green building assessment systems. Energy efficiency is defined as improve energy efficiency through building positioning, lighting, heating and best practices [24]. EE has become the highest priority for GreenRE compare to others criteria and also other green building systems with about $59 \%$ of the total score. According to [25], most assessment programs have higher energy scores as future energy demand will increase. There are different areas of assessment which have been highlighted under EE such as Overall Thermal Transfer Value (OTTV), renewable energy and lightning. In a green building, it is important to involve some elements such as energy efficient cooling system, renewable energy, energy efficiency lighting to ensure the sustainability level of the building. Involving this elements enable the project to achieve credit during green building evaluation. By promoting more efficient building development or by improving the energy efficiency of buildings, climate change related issues can be addressed and buildings can be mitigated from the surrounding

environment [26].Therefore, the energy efficiency of buildings has become the primary goal of energy policy at the regional level, national level and international levels [27].

Indoor environmental quality (IEQ) is given the second priority in most of the green building assessment systems, except MyCREST. IEQ is also one of the key components in assessing building projects aimed at achieving sustainable development. IEQ has four main elements, namely indoor air quality (air flow $\mathrm{CO} 2$ concentration, heat (temperature and humidity), lightning and noise comfort [28]. According to [24], IEQ can be defined as achieving quality of air, visual, acoustic and thermal comfort of indoor environments through the application of low volatile organic compound (VOC), high quality of air filtration and control the temperature, motion and humidity. PH JKR has allocated $22 \%$ for IEQ, which is the highest as compared to GBI and 
GreenRE which is $21 \%$ and 5\%.IEQ has gained $12.0 \%$ of the total score. There are some strategy that enable construction industry players to achieve credits during the evaluation of green building projects such as used of low volatile organic compound. Used of low volatile organic compound products can reduce adverse effects of the finishes of internal air pollutants on the health of the occupants [29]. IEQ characteristics is the solution towards overheating aspects [28].

In [30] have conducted a research in Taiwan to study the water efficiency in green building. The research has studied 1320 cases with certification during in Taiwan and it stated that the average water saving rate was approximately $37.6 \%$. This showed that green buildings can help to save more water as compare to conventional buildings. Therefore, water efficiency (WE) is given a similar focus for every green building assessment systems. Water efficiency stated in green building assessment systems refer to the decrease in the usage of water as well as decrease in the wastage of water [31]. It is an approaches of using good practices and improved technologies to minimise the amount of water used in our daily life [32]. The normalized scores for WE are ranging from $7 \%$ to $10 \%$ where GBI and PH JKR being the highest. Water considered as a valuable and limited resource, thereby all the assessment systems included water efficiency to search for sustainable water management and use. Green building assessment systems in Malaysia evaluated WE in several aspects such as water harvesting and recycling, used of water efficient fittings and water consumption of cooling tower. Besides that, innovation is also given a similar focus for every green building assessment systems. Innovation in green building assessment systems refer to the aspects that encourage the construction projects to accomplish innovative or extraordinary performance [26]. The normalized scores for innovation are ranging from $4 \%$ to $7 \%$ where GreenRE being the lowest and GBI being the highest. It is strongly recommend that any new method to improve the sustainability of buildings [25]. Green building assessment systems evaluated innovation in few aspects such as innovation in buildings' design and environmental design initiatives or any green features which will lead positive environmental impact.
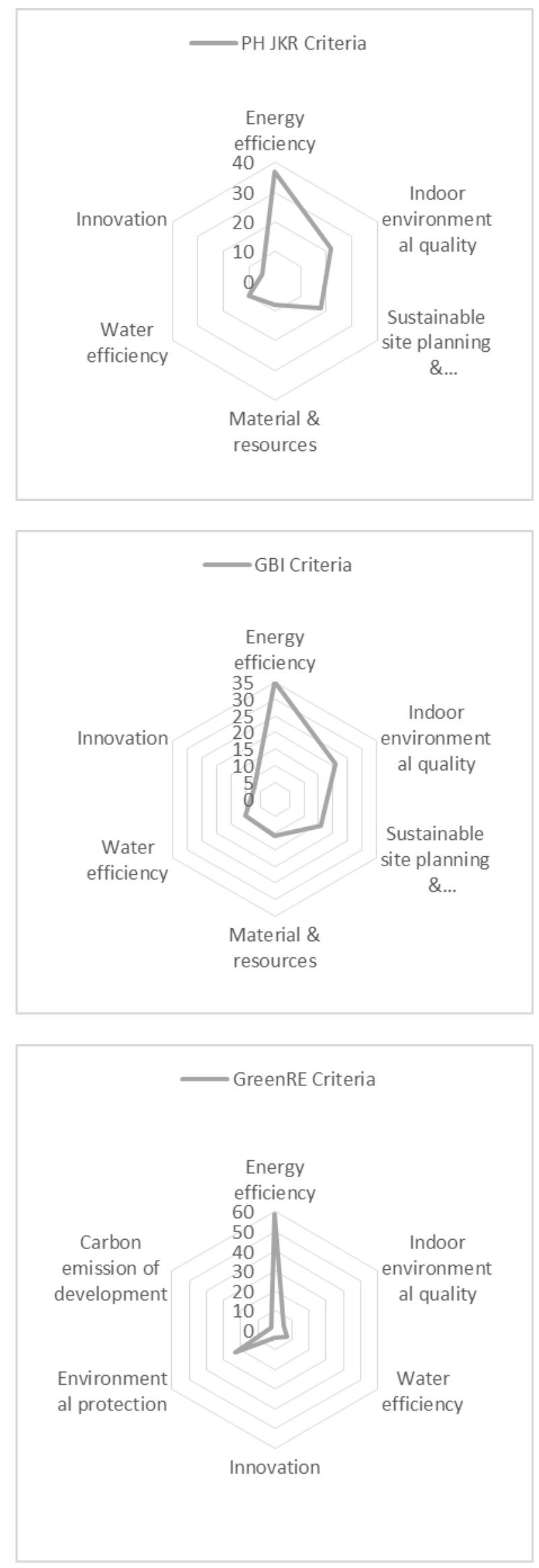

Published By: 


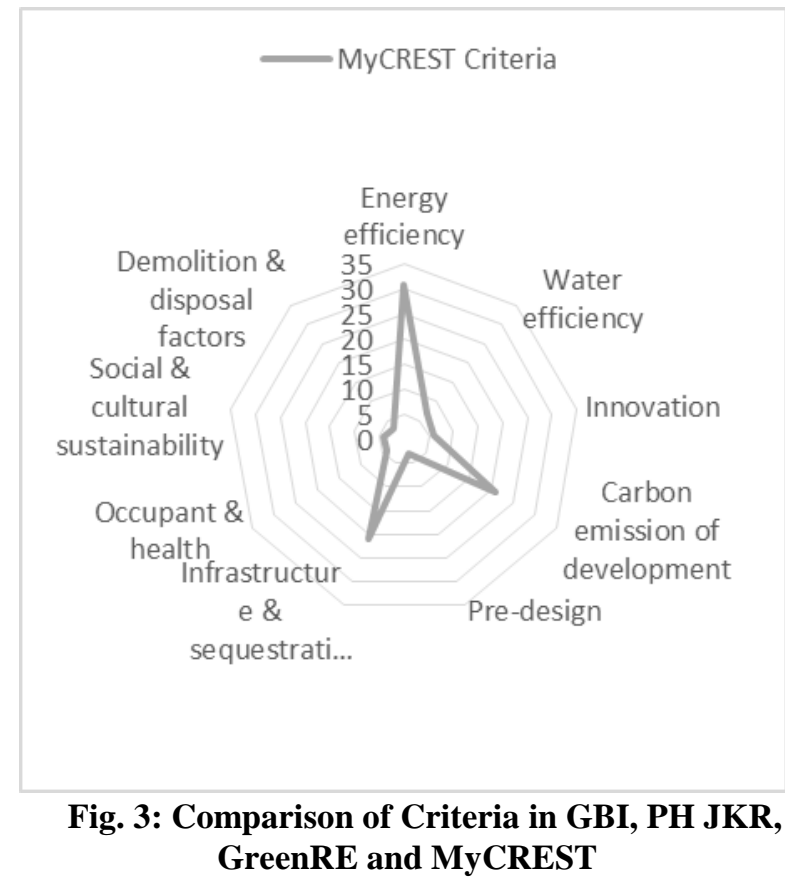

GBI and PH JKR have gave a consideration on both material and resources, and sustainable site planning and management. The site area takes into account aspects related to the protection and protection of local environmental characteristics and biological species, natural disasters and risks associated with site characteristics and facilities, and the impact of urban design on buildings [33]. Sustainable site planning and management should consider by site [14]. Site planners should consider how to effectively reduce the disturbed areas of green building projects and should prevent development in inappropriate locations and minimize the environmental impact of buildings on the site [29].Site location and protection should prevent development of unsuitable sites, whereas the recent aspect is to support habitat protection and encourage biodiversity. It is important to select the appropriate site for development to minimize the negative impact towards the environment. It has been assessed in few aspects such as site planning, construction management, environment management and transportation.

The process of producing building materials and the use of large amounts of natural resources during construction [26]. Given the environmental impact of greenhouse gas emissions and the importance of emissions reflected in building materials, it is important to reveal the environmental performance of critical building materials. Therefore, material and resources also play a role in GBI and PH JKR. Materials and resources can be defined as the use of environmentally friendly materials and the implementation of appropriate construction waste management [24]. It is agreed by [26] where material and resources has emphasize the use of materials that have the low environmental impact and also to encourage resource efficiency through efficient management and reduce of construction waste. The life cycle assessment of the materials starts from the extraction of the materials until the disposal of the materials. Therefore, certain areas have been focus under material and resources such as recycled and planners in minimizing disturbed areas and project methods

reused materials, sustainable resources, green product and waste management during construction.

Environmental protection criteria have play an important role in GreenRE. Environmental protection has gained 23\% out of total score and it is the second importance criteria in GreenRE. Environmental protection highlighted certain are such as greenery provision, storm water management and refrigerants. Next, GreenRE and MyCREST have gave a consideration on carbon emission of development when evaluating the sustainability of green building project. The aims of carbon emission of development is to calculate the carbon emission caused from the associated energy used during construction and operational phase of development [34]. Carbon emissions are identified based on operational carbon footprint calculations for buildings' energy and water consumption. It enabled the industry players to identify and understand the carbon emitted during the project. Besides that, carbon emissions of development can be used to identify the carbon debt and quantify environmental impact and embodied energy, as well as allow benchmarking of projects over time by using Building and Construction Authority (BCA)'s online embodied carbon calculator.

There are some other criteria that only considered by MyCREST such as pre-design, occupant and health, infrastructure and sequestration, demolition and disposal factors, social and cultural sustainability. MyCREST has taking into an entire life-cycle of the built environment. Therefore, the criteria that used to assess the life-cycle of the building have been included in MyCREST.

\section{CONCLUSION}

This paper analyzed the green building assessment systems and criteria used to evaluate the sustainability of green building project in Malaysia. One of the major difficulties in constructing an index is the determination of an appropriate mean to aggregate multidimensional variables into an index [35]. According to the study and analysis of the green building assessment systems and the criteria stated in the green building assessment systems, it can be concluded each of the green building has their own culture or utilize different criteria in evaluating the sustainability of the green building projects. The credit score allocated for different criteria may be different among the green building assessment systems. However, this green building systems also share some similar criteria. It can be concluded that energy efficiency has given the highest consideration. It clearly showed that energy related issue has play an important role in the development of green building. This showed that all of the green building assessment systems have given a huge focus on energy efficiency. Furthermore, the radar diagram for GBI and PH JKR are similar in shape. This two green building assessment systems have used the same criteria while evaluating the sustainability of the green building projects but the subcriteria are slightly different. Next, since MyCREST is used to evaluate the entire life-cycle of the building, more criteria have taken into consideration. 
There are many factors that promote the rapid growth of green buildings, including the increasingly serious environmental pollution problems, the introduction and development of some green building technologies, the implementation of green building assessment systems, including a series of standards for evaluating green building projects, and continuous improvement of the quality of the building environment requirements, and other relevant regulations and policies [36]. This research has identified the four main green building assessment systems that used widely in Malaysia. It is essential for the regional planning and development by policy makers in order to identify and conduct possible efforts [37]. However, this research is only limited to four green building assessment systems in Malaysia. There are also some others green building assessment systems which have not been discussed in this research. Therefore, further research can be developed focusing on other green building assessment systems which has been eliminated in this research.

\section{ACKNOWLEDGMENT}

The authors would like express thank to UniversitiTeknikal Malaysia Melaka for allowing to assess all the data and information required in this research. The authors would like to grab the opportunity to express sincere appreciation to PerbadananTeknologiHijau Melaka (PTHM) and GreenRE for sharing their professional knowledge and ideas in this paper.

\section{REFERENCES}

1 E. M. Elias, and C. K. Lin, "The empirical study of green buildings (residential) implementation: Perspective of house developers," Procedia Environmental Sciences, 28, 2015, pp. 708-716.

2 N. D. B. Afandi, Green development: Developers' motivation, expectation and experience. Master thesis, Pulau Pinang: Universiti Sains Malaysia, 2015.

3 F. R. Azmi, H. Musa, A. R. Abdullah, N. A. Othman, and S. Fam, "Analyzing the awareness of green technology in Malaysia practices," Mechanical Engineering Research Day, 2017, pp. 252-254.

4 Y. Li, X. Chen, X. Wang, Y. Xu, and P. H. Chen, "A review of studies on green building methods by comparative analysis," Energy Build., 146, 2017, pp. 152-159.

5 S. Pandey, Impact of green building rating systems on the sustainability and efficacy of green buildings case analysis of green building index. 2016, Available: https://scienceimpact.mit.edu/sites/default/files/document s/Pandey.pdf.

6 X. Zhang, and Y. Wang, "How to reduce household carbon emissions: A review of experience and policy design considerations," Energy Policy, 102, 2017, pp. 116-124.

7 S. F. Fam, A. A. Jemain, and W. Z. W. Zin, "Spatial analysis of socioeconomic deprivation in Peninsular Malaysia," International Journal of Arts and Sciences, 4(17), 2011, pp. 241-255.

8 U. Berardi, "Sustainability assessments of buildings, communities, and cities," in Assessing and Measuring Environmental Impact and Sustainability, J. J. Klemes, Ed. Oxford: Butterworth-Heinemann, 2015, pp. 497-545.

9 F. R. Azmi, H. Musa, A. R. Abdullah, N. A. Othman, and $\mathrm{S}$. Fam, "Analyzing the awareness of green technology in
Malaysia practices," Mechanical Engineering Research Day, 2017, pp. 252-254.

10 Y. Li, W. Yu, B. Li, and R. Yao, "A multidimensional model for green building assessment: A case study of a highest-rated project in Chongqing," Energy and Buildings, 125, 2016, pp. 231-243.

11 Environmental Protection Agency (EPA), Green building. 2016, Available: https://archive.epa.gov/greenbuilding/web/html/.

12 World Green Building Council, About green building 2019, Available: https://www.worldgbc.org/about-greenbuilding.

13 S. Alsanad, "Awareness, drivers, actions, and barriers of sustainable construction in Kuwait," Procedia Eng., 118, 2015, pp. 969-983.

14 S. M. Algburi, A. A. Faieza, and B. T. H. T. Baharudin, "Review of green building index in Malaysia; Existing work and challenges," International Journal of Applied Engineering Research, 11(5), 2016, pp. 3160-3167.

15 F. R. Azmi, H. Musa, F. Shahbodin, H. Hazmilah, and S. Fam, "Green human resource management: A case of Malaysia," IOSR Journal of Business and Management, 20(3), 2018, pp. 77-80.

16 J. K. W. Wong, and J. Zhou, "Enhancing environmental sustainability over building life cycles through green BIM: A review," Automation in Construction, 57, 2015, pp. 156-165.

17 J. K. W. Wong, and K. L. Kuan, "Implementing "BEAM Plus' for BIM-based sustainability analysis," Automation in Construction, 44, 2014, pp. 163-175.

18 D. T. Doan, A. Ghaffarianhoseini, N. Naismith, T. Zhang, A. Ghaffarianhoseini, and J. Tookey, "A critical comparison of green building rating systems," Building and Environment, 123, 2017, pp. 243-260.

19 S. F. Fam, N. Ismail, A. L. Maukar, H. Yanto, D. D. Prastyo, A. A. Jemain, and Z. L. Chuan, "Weighting methods in the construction of area deprivation indices," Journal of Fundamental and Applied Sciences, 10(6S), 2018, pp. 2655-2668.

20 I. C. S. Illankoon, V. W. Tam, K. N. Le, and L. Shen, "Key credit criteria among international green building rating tools," Journal of Cleaner Production, 164, 2017, pp. 209-220.

21 Z. Wu, L. Shen, A. T. W. Yu, and X. Zhang, "A comparative analysis of waste management requirements between five green building rating systems for new residential buildings," J. Clean. Prod., 112, 2015, pp. 895-902.

22 C. C. Ohueri, W. I. Enegbuma, R. Kenley, C. C. Ohueri, W. I. Enegbuma, and R. Kenley, "Energy efficiency practices for Malaysian green office building occupants," Built Environment Project and Asset Management, 8(2), 2018, pp. 134-146.

23 M. Nilashi, R. Zakaria, O. Ibrahim, M. Z. A. Majid, R. M. Zin, M. W. Chugtai, N. I. Z. Abidin, S. R. Sahamir, and D. A. Yakubu, "A knowledge-based expert system for assessing the performance level of green buildings," Knowledge-Based Syst., 86, 2015, pp. 194-209.

24 J. Ignatius, A. Rahman, M. Yazdani, J. Šaparauskas, and S. H. Haron, "An integrated fuzzy ANP-QFD approach for green building assessment," J. Civ. Eng. Manag., 22(4), 2016, pp. 551-563.

25 S. N. Kamaruzzaman, E. C. W. Lou, N. Zainon, N. S. M. Zaid, and P. F. Wong, "Environmental assessment schemes for non-domestic buildingrefurbishment in the Malaysian context," Ecol. Indic., 69, 2016, 2016, pp. $548-558$. 
26 CIDB, CIDB built it green.pdf. 2018.

27 F. Asdrubali, G. Baldinelli, F. Bianchi, and S. Sambuco, "A comparison between environmental sustainability rating systems LEED and ITACA for residential buildings," Build. Environ., 86, 2015, pp. 98-108.

28 M. M. G. M. M. Raid, A. C. Kasim, and Khadijah Hussin, "Impact of Indoor Environmental Quality (IEQ) and Innovation (IN) features on residential property price in Malaysia: A review," 10th International Conference on Earthquake Resistant Engineering Structures, 2015, pp. 63-73.

29 Green Building Index, GBI assessment criteria for Residential New Construction (RNC). Available: https://new.greenbuildingindex.org/Files/Resources/GBI \%20Tools/GBI\%20RNC\%20Residential\%20Tool\%20V2 $.0 \% 20$ Final.pdf.

30 C. L. Cheng, J. J. Peng, M. C. Ho, W. J. Liao, and S. J. Chern, "Evaluation of water efficiency in green building in Taiwan," Water (Switzerland), 8(6), 2016, pp. 1-11.

31 O. Das, P. Bera, and S. Moulick, "Water conservation aspects of green buildings," Int. J. Res. Eng. Technol., 4(25), 2015, pp. 75-79.

32 GreenRE, Design reference guide. 2018, Available: http://greenre.org/uploads/1/0/7/1/107142097/nrb_v3.1_rev1.1.pdf.

33 B. Mattoni, C. Guattari, L. Evangelisti, F. Bisegna, P. Gori, and F. Asdrubali, "Critical review and methodological approach to evaluate the differences among international green building rating tools," Renew. Sustain. Energy Rev., 82, 2018, pp. 950-960.

34 GreenRE, Design reference guide. 2018, Available: http://greenre.org/uploads/1/0/7/1/107142097/nrb_v3.1__rev1.1.pdf.

35 S. F. Fam, N. Ismail, and A. A. Jemain, "Geographical and socio-economic analysis in Peninsular Malaysia," The Social Sciences, 12(9), 2017, pp. 16951704.

36 M. W. M. Shafiei and H. Abadi, "The impacts of green building index towards energy consumption in Malaysia," Australian Journal of Basic and Applied Sciences, 11(4), 2017, pp. 131-139.

37 S. F. Fam, A. A. Jemain, and K. Ibrahim, "The association between material deprivation and relative risk of infant mortality in Peninsular Malaysia," International Journal of Arts and Sciences, 4(17), 2011, pp. 257-269.

\section{AUTHORS PROFILE}

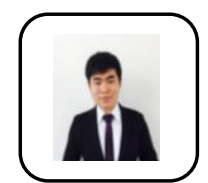

Ong Boon Zian, Master of science in Technology Management, postgraduate student in Faculty of Technology Management and Technopreneurship, Universiti Teknikal Malaysia Melaka (UTeM)

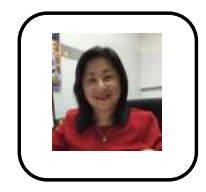

Soo-Fen Fam, hold B.SC. in Statistics with Management, M.Sc. in Quality and Productivity Improvement and Doctoral Degree in Statistics from Universiti Kebangsaan Malaysia (UKM). Currently, working as a senior lecturer in the Faculty of Technology Management and Technopreneurship (FPTT), Universiti Teknikal Malaysia Melaka (UTeM). For further information, please visit her blog, soofenfam.blogspot.com.

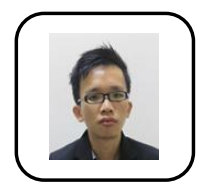

Chuan Zun Liang, a senior lecturer from Universiti Malaysia Pahang (UMP). He obtained his doctorates in Statistics from Universiti Kebangsaan Malaysia (UKM). His field of expertise are Image Processing, Pattern Recognition, Statistical Modelling, Time Series and Spatial Analysis

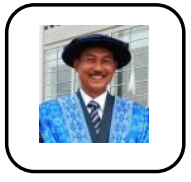

Sentot Imam Wahjono, is the Associate Professor in the Management Department of the University of Muhammadiyah Surabaya, Indonesia. Doctorates were obtained from Malang State University, Indonesia and the University of Queensland, Brisbane, Australia. He teaches HR and Financial Management. He has been active in the office of Deloitte Touche International Management Consultant. The focus of his current research is in the field of Crowdfunding and Family Business

Tan Ying Ying,Master of science in Entrepreneurship, postgraduate student in Faculty of Technology Management and Technopreneurship 